\title{
Harnessing DNA Replication Stress for Novel Cancer Therapy
}

\author{
Huanbo Zhu ${ }^{1,+}$, Umang Swami ${ }^{2,+} \mathbb{D}$, Ranjan Preet ${ }^{1}$ and Jun Zhang ${ }^{1,3, *}$ \\ 1 Division of Medical Oncology, Department of Internal Medicine, University of Kansas Medical Center, \\ 3901 Rainbow Blvd, Kansas City, KS 66160, USA; hzhu2@kumc.edu (H.Z.); rpreet@kumc.edu (R.P.) \\ 2 Division of Oncology, Department of Internal Medicine, Huntsman Cancer Institute, University of Utah, \\ 2000 Circle of Hope, Salt Lake City, UT 84112, USA; umang.swami@hci.utah.edu \\ 3 Department of Cancer Biology, University of Kansas Cancer Center, 3901 Rainbow Blvd, Kansas City, \\ KS 66160, USA \\ * Correspondence: jzhang3@kumc.edu; Tel.: +1-(913)-588-8150; Fax: +1-(913)-588-4085 \\ $+\quad$ H.Z. and U.S. contributed equally.
}

Received: 2 July 2020; Accepted: 20 August 2020; Published: 25 August 2020

\begin{abstract}
DNA replication is the fundamental process for accurate duplication and transfer of genetic information. Its fidelity is under constant stress from endogenous and exogenous factors which can cause perturbations that lead to DNA damage and defective replication. This can compromise genomic stability and integrity. Genomic instability is considered as one of the hallmarks of cancer. In normal cells, various checkpoints could either activate DNA repair or induce cell death/senescence. Cancer cells on the other hand potentiate DNA replicative stress, due to defective DNA damage repair mechanism and unchecked growth signaling. Though replicative stress can lead to mutagenesis and tumorigenesis, it can be harnessed paradoxically for cancer treatment. Herein, we review the mechanism and rationale to exploit replication stress for cancer therapy. We discuss both established and new approaches targeting DNA replication stress including chemotherapy, radiation, and small molecule inhibitors targeting pathways including ATR, Chk1, PARP, WEE1, MELK, NAE, TLK etc. Finally, we review combination treatments, biomarkers, and we suggest potential novel methods to target DNA replication stress to treat cancer.
\end{abstract}

Keywords: DNA replication stress; ATR; Chk1; PARP; WEE1; MELK; TLK; NAE; NEDD8; DNA damage response

\section{Introduction}

Precise, accurate, and error-free DNA duplication of the entire cell genome through DNA replication is necessary for the continuation of controlled, cellular proliferation [1]. It is a tightly regulated process comprising a vast number of signaling pathways that ensure that the genome is replicated only once with high fidelity [1]. To maintain genomic integrity, cells deploy the DNA damage response (DDR) system, a collective term for various signaling molecules and enzymes produced by more than 450 genes [2] which either activate DNA repair or induce cellular senescence or apoptosis [3].

Because of mutations including oncogenic activation or tumor suppressor gene inactivation, the DDR system may fail to safeguard genomic integrity and fidelity, and DNA replication may persist despite uncorrected DNA errors in response to proliferation signals leading to replication stress [3]. DNA replication stress is described as an alteration in error-free DNA replication including a slowdown of DNA synthesis and stalling of replication forks leading to genomic instability [3]. However, further enhancing replication stress in cancer cells can paradoxically lead to cell death through the induction of "mitotic catastrophe"-a type of cell death caused by premature or inappropriate entry of cells into mitosis prior to the completion of DNA synthesis-therefore offering a novel approach to treat cancer. 
In this review, we explore the current strategies and summarize our current understanding of ways to harness replication stress to treat cancer. We focus on emerging approaches and propose novel ideas and biomarkers to predict responses.

\section{Underlying Mechanisms of Replication Stress and Rationale in Cancer Therapy}

Human DNA has daily exposure to a variety of insults which are both exogenous and endogenous in nature. Exogenous insults include ultraviolet radiation, ionizing radiation, genotoxic chemicals, and environmental stresses. While endogenous stresses include reactive oxygen species (ROS), spontaneous disintegration of chemical bonds, replication errors, DNA base mismatches, topoisomerase-DNA complexes, DNA methylation etc. [4]. In normal cells, damaged DNA is repaired by various mechanisms including base-excision repair (BER), nucleotide-excision repair (NER), mismatch repair (MMR), homologous recombination (HR), and non-homologous end-joining (NHEJ). In general, single-strand breaks (SSBs) are repaired by BER, NER, and MMR while double-strand breaks (DSBs) are repaired by HR and NHEJ [5]. If DNA repair is not possible, cell cycle progression through G2-M phase is blocked, and the cells enter senescence or apoptosis [3,6].

However, a faulty DDR system or altered checkpoints along with persistent growth signaling can lead to the replication of damaged DNA, thus, leading to DNA synthesis slowdown and/or replication fork stalling, characteristic of DNA replication stress [3,6,7]. "Fork stalling" can occur because of multiple reasons including, limited substrate availability (e.g., shortage of histones or deoxyribonucleotide triphosphates (dNTPs), abnormal DNA secondary structures or topology, RNA-DNA hybrids (R-loops), DNA-protein crosslinks, torsional stress, and cessation of DNA polymerase activity etc., [8,9]. Stalled forks initiate the firing of neighboring dormant origins during active replicative mini-chromosome maintenance (MCM) so that they can continue unwinding DNA for a few hundred base pairs downstream, which exposes single-stranded DNA (ssDNA) [3,8]. ssDNAs recruit/activate Ataxia telangiectasia and Rad3-related protein (ATR) through ATR interacting protein (ATRIP) which leads to phosphorylation of multiple targets including checkpoint kinase 1 (Chk1) [3,8]. All these events help to reduce replication stress [3].

In normal cells, ATR in combination with other DDR proteins and checkpoint molecules, prevent untimely mitosis of cells harboring damaged DNA [10]. But in cancer cells with replicative stress, stalled forks exist and multiple origins are fired, leading to dNTP pool depletion [11]. This further enhances replication stress leading to the generation of more non-progressive forks [11]. When there is an excess of ssDNA, it depletes available replication protein A (RPA), which causes forks to collapse leading to double-strand DNA (dsDNA) break generation [3,9,11,12]. If these cells enter mitosis their damaged, non-replicated DNA can cause "mitotic catastrophe" leading to cell death $[13,14]$. However, it needs to be noted that even though replicative stress is present in cancer cells it occurs only at low to mild levels as its excess can cause mitotic catastrophe [6,7,15].

The persistence of replicative stress is observed almost exclusively in precancerous and cancer cells and is rarely seen in normal cells even with rapid proliferation [7], which offers potential therapeutic selectivity in cancer cells. This is likely due to multiple reasons including oncogene activation, inactivation of tumor suppressor genes, higher levels of ROS, defective DDR system etc., in cancer cells [3]. However, as discussed even though replicative stress causes genomic instability and mutations which are considered a hallmark of cancer [16], it can be paradoxically harnessed to treat cancer by exploiting it to push cancer cells into replicative catastrophe [3]. This can theoretically be done by either targeting DNA synthesis, replication, repair, promoting cells to enter $\mathrm{S}$ phase or pushing their premature entry into $\mathrm{M}$ phase [3]. Figure 1 summarizes the major pathways involved in DNA replication stress and current and potential strategies to target them. 


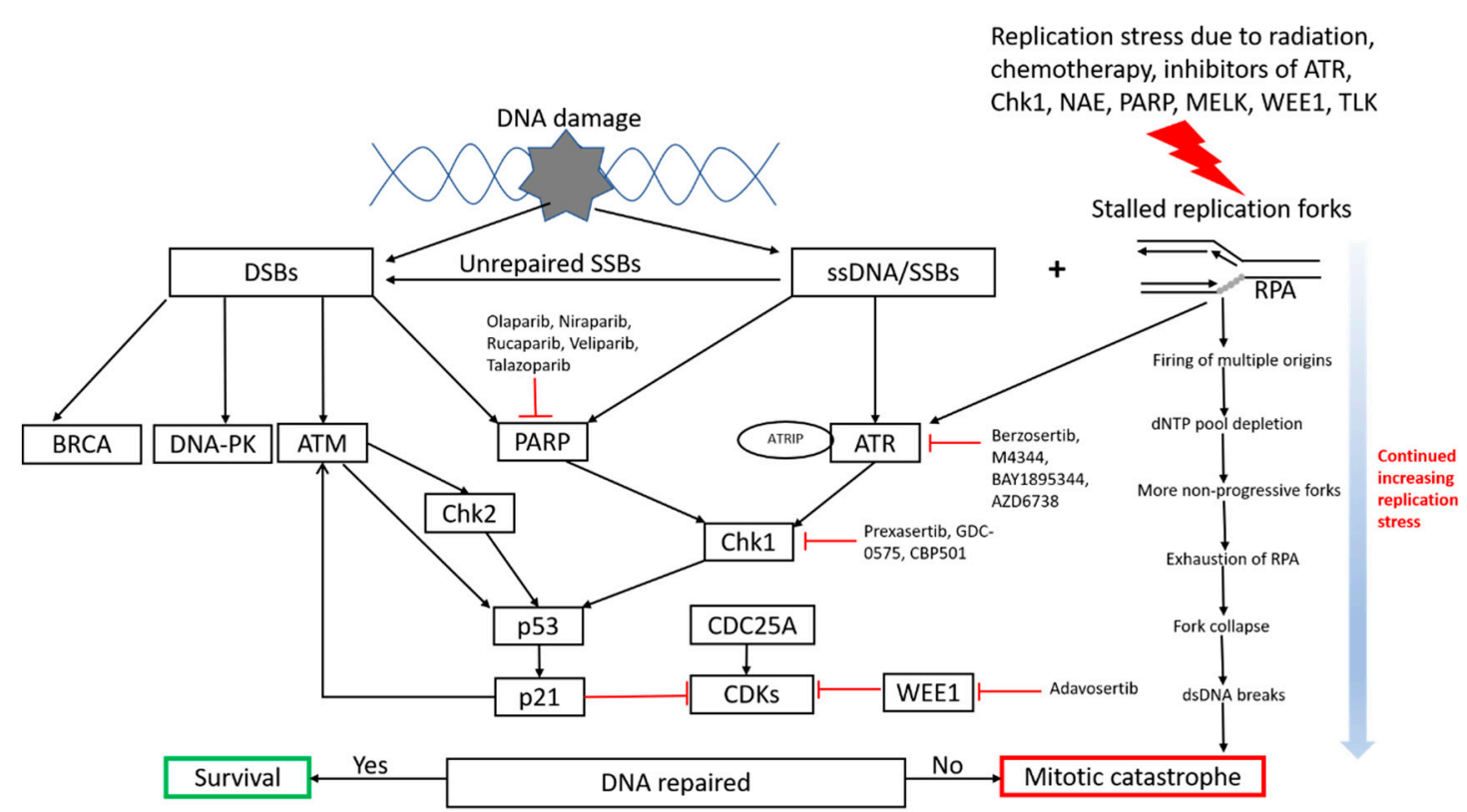

Figure 1. Current and potential strategies to target DNA replication stress. The major pathways involved in DNA damage response and replication stress are illustrated in this flowchart underlying the details of replication stress and cancer therapy targets. (ATR: Ataxia telangiectasia and Rad3-related protein; ATRIP: Ataxia telangiectasia and Rad3-related protein interacting protein; RPA: replication protein A; ATM: ataxia telangiectasia mutated; DNA-PK: DNA-dependent protein kinase; CDK: cyclin-dependent kinase; DSBs: double strand breaks; SSBs: single strand breaks; ssDNA: single-stranded DNA; dNTP: deoxyribonucleotide triphosphates).

\section{Potential Pathways to Modulate Replication Stress for Cancer Treatment}

\subsection{Traditional Approaches-Radiation and Chemotherapy}

Radiation-induced DNA damage ranges from base and sugar damage to cross-links, SSBs and DSBs [17] which interfere with DNA replication. However, DSBs are mostly responsible for radiation lethality to cells [17].

Multiple chemotherapeutic agents induce and modulate DNA replication stress in their own unique ways. Some of them like DNA cross-linking agents, topoisomerase inhibitors and alkylating agents act primarily by causing DNA damage. This further induces and enhances replication stress in cancer cells, while agents targeting nucleotide synthesis and inhibiting DNA polymerases act by thwarting the activity of replisomes thereby, increasing replication stress and activating the replication stress response [8]. As discussed in Table 1, some alkylating agents (e.g., cyclophosphamide, ifosfamide etc.,) and alkylating-like agents (platinum compounds such as cisplatin, carboplatin etc.,) cause inter- and intra-strand cross-links between DNA bases [18,19]. Inter-strand cross-links hinder DNA unwinding [20] and intra-strand cross-links misincorporate nucleotides and produce alterations in template strand [21]. These cross-links can delay or stall the progression of replication forks and lead to and increased replication stress $[3,8]$.

Chemotherapies like gemcitabine, cytarabine, fludarabine, 5-fluorouracil, and hydroxyurea slow or stall replication fork progression by directly reducing dNTP pools leading to direct inhibition of DNA synthesis and/or by inhibiting DNA polymerases. Nucleoside analogs like gemcitabine, fludarabine, and cytarabine are incorporated into replicated DNA (or RNA) strand after converting into triphosphates and inhibit replication or transcription elongation [22]. Gemcitabine (irreversibly) and hydroxyurea (reversibly) inhibit ribonucleotide reductase [23], while 5-fluorouracil inhibits thymidylate synthetase [24]. This also depletes the available dNTP pool, the building block of DNA strands which slows and stalls replication fork progression [3]. 
Table 1. Agents approved by United States Food and Drug Administration targeting DNA replication stress.

\begin{tabular}{|c|c|c|}
\hline Mechanism & Agents & Approved Indications \\
\hline \multirow{5}{*}{ DNA mis incorporation/modification } & Cyclophosphamide & $\begin{array}{l}\text { HL, NHL, multiple myeloma, ALL, AML, breast cancer, CLL, } \\
\text { CML, CLL, CML, mycosis fungoides, neuroblastoma, } \\
\text { ovarian cancer, retinoblastoma }\end{array}$ \\
\hline & Temozolomide & Anaplastic astrocytoma, glioblastoma multiforme \\
\hline & Cisplatin & Bladder, testicular, ovarian cancer \\
\hline & Carboplatin & Ovarian cancer \\
\hline & Oxaliplatin & Colorectal cancer \\
\hline \multirow{5}{*}{ Ribonucleotide reductase inhibitor } & Gemcitabine & NSCLC, breast, ovarian, pancreatic cancer \\
\hline & Clofarabine & ALL \\
\hline & Fludarabine & CLL \\
\hline & Cytarabine & $\begin{array}{c}\text { ALL, AML, CML, meningeal leukemia, lymphomatous } \\
\text { meningitis }\end{array}$ \\
\hline & Hydroxyurea & CML, HNSCC \\
\hline \multirow{3}{*}{ Thymidylate synthetase inhibition } & 5-Fluorouracil & Breast, colorectal, gastric, pancreatic cancer \\
\hline & Capecitabine & Breast, colorectal caner \\
\hline & Pemetrexed & NSCLC, malignant pleural mesothelioma \\
\hline \multirow{2}{*}{ Topoisomerase I inhibitor } & Irinotecan & Colorectal cancer, pancreatic cancer \\
\hline & Topotecan & Cervical, ovarian, SCLC \\
\hline \multirow{2}{*}{ Topoisomerase II inhibitor } & Etoposide & SCLC, testicular cancer \\
\hline & Doxorubicin & $\begin{array}{l}\text { ALL, AML, HL, NHL, neuroblastoma, SCLC, soft tissue and } \\
\text { bone sarcomas, Wilms tumor, thyroid, ovarian, breast, } \\
\text { gastric, transitional cell bladder cancer }\end{array}$ \\
\hline DNA methyltransferase inhibitor & Decitabine & MDS \\
\hline Folic acid reductase inhibitor & Methotrexate & $\begin{array}{l}\text { ALL, gestational trophoblastic disease, mycosis fungoides, } \\
\text { NHL, osteosarcoma, head and neck, breast, lung cancer }\end{array}$ \\
\hline DNA replication inhibitor & Nelarabine & T-cell ALL, T-cell lymphoblastic lymphoma \\
\hline $\begin{array}{l}\text { Blockage of synthesis and metabolism } \\
\text { of purine nucleotides }\end{array}$ & Thioguanine & AML \\
\hline $\begin{array}{l}\text { Inhibition of nucleotide synthesis and } \\
\text { nucleotide analogue incorporation }\end{array}$ & $\begin{array}{l}\text { Trifluridine and } \\
\text { Tipiracil } \\
\text { Hydrochloride }\end{array}$ & Colorectal cancer \\
\hline \multirow[t]{4}{*}{ PARP inhibitors } & Olaparib & $\begin{array}{l}\text { BRCA-mutated, HER2-negative metastatic breast cancer, } \\
\text { BRCA mutated advanced ovarian cancer, as maintenance } \\
\text { treatment for recurrent epithelial OPFTC in patients } \\
\text { experiencing a complete or partial response to } \\
\text { platinum-based chemotherapy }\end{array}$ \\
\hline & Rucaparib & $\begin{array}{l}\text { BRCA mutated epithelial OPFTC after two or more } \\
\text { chemotherapies, maintenance treatment of recurrent } \\
\text { epithelial OPFTC that are in a complete or partial response } \\
\text { to platinum-based chemotherapy }\end{array}$ \\
\hline & Niraparib & $\begin{array}{l}\text { Maintenance treatment of recurrent epithelial OPFTC in } \\
\text { patients undergoing complete or partial response to } \\
\text { platinum-based chemotherapy }\end{array}$ \\
\hline & Talazoparib & $\begin{array}{l}\text { Treatment of adult patients with deleterious or suspected } \\
\text { deleterious germline breast cancer susceptibility gene } \\
\text { (BRCA)-mutated (gBRCAm) human epidermal growth } \\
\text { factor receptor } 2 \text { (HER2)-negative locally advanced or } \\
\text { metastatic breast cancer }\end{array}$ \\
\hline
\end{tabular}

Data retrieved from: https://www.accessdata.fda.gov/scripts/cder/daf/ Retrieval date 04/21/2020 and https: //www.cancer.gov/about-cancer/treatment/drugs Retrieval date 04/21/2020. HNSCC—head and neck squamous cell carcinoma, NSCLC — non-small cell lung cancer, SCLC—small cell lung cancer, NET—neuroendocrine tumors, OPFTC — ovarian, primary peritoneal, or fallopian tube cancer, GEJ—gastroesophageal junction, CLL—chronic lymphocytic leukemia, PLL—prolymphocytic leukemia, NHL—non Hodgkin's lymphoma, AML—acute myelogenous leukemia, MDS-myelodysplastic syndrome, CMML-chronic myelomonocytic leukemia, MPN—myeloproliferative neoplasm, CLL—chronic lymphocytic leukemia, ALL—acute lymphoblastic leukemia. 
Topoisomerases control DNA topology by catalyzing the cleavage and resealing of one or both DNA strands thereby, managing supercoils and replication [25]. Topoisomerase inhibitors can induce replication stress, they can either physically hinder replication forks [26,27] or induce fork reversal as with topoisomerase I inhibitors (irinotecan and topotecan) [28] or activate Chk1 as with topoisomerase II inhibitors (etoposide and doxorubicin) [29].

\subsection{New Emerging Approaches and Strategies}

\subsubsection{ATR-Chk1 Pathway}

ATR along with ataxia telangiectasia mutated (ATM) and the DNA-dependent protein kinase (DNA-PK), are the key components of the DDR system [30]. ATM and DNA-PK primarily respond to DSBs while ATR responds to replication stress including ssDNA generated at stalled replication forks or resected DSBs [7,30,31]. Table 2 summarizes the current clinical trials of novel agents targeting DNA replication stress.

Table 2. Current ongoing trials of unapproved novel agents mainly targeting DNA replication stress.

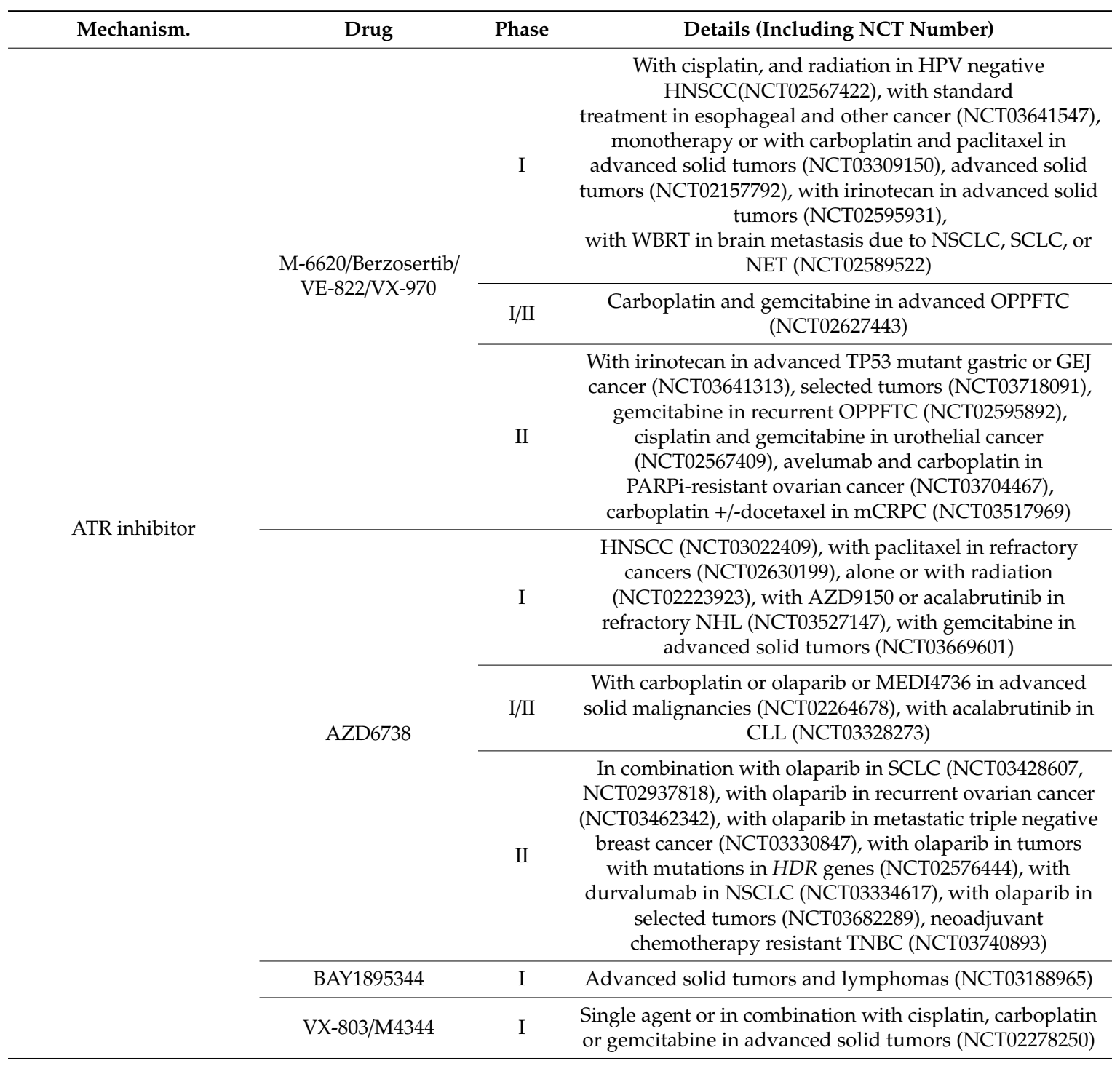


Table 2. Cont.

\begin{tabular}{|c|c|c|c|}
\hline Mechanism. & Drug & Phase & Details (Including NCT Number) \\
\hline \multirow[t]{3}{*}{ Chk1 inhibitor } & \multirow[t]{2}{*}{$\begin{array}{l}\text { LY2606368 } \\
\text { (Prexasertib) }\end{array}$} & I & $\begin{array}{l}\text { With cytarabine and fludarabine in AML and high risk } \\
\text { MDS (NCT02649764), advanced cancer (NCT02778126, } \\
\text { NCT02514603, NCT01115790), refractory solid tumors in } \\
\text { pediatric patients (NCT02808650), with ralimetinib in } \\
\text { selected cancers (NCT02860780), with cisplatin/cetuximab } \\
\text { and radiation in HNSCC (NCT02555644), with olaparib in } \\
\text { advanced solid tumors (NCT03057145), with LY3300054 in } \\
\text { advanced solid tumors (NCT03495323), with } \\
\text { chemotherapy or targeted agents in advanced cancer } \\
\text { (NCT02124148), with mitoxantrone, etoposide, and } \\
\text { cytarabine in refractory AML and high risk MDS } \\
\text { (NCT03735446) }\end{array}$ \\
\hline & & II & $\begin{array}{l}\text { Extensive stage SCLC (NCT02735980), in BRCA1/2 } \\
\text { mutated selected cancers (NCT02203513), in solid tumors } \\
\text { with replicative stress or HDR deficiency (NCT02873975), } \\
\text { refractory ovarian cancer (NCT03414047) }\end{array}$ \\
\hline & CBP501 & I & $\begin{array}{l}\text { With cisplatin and nivolumab in advanced solid tumors } \\
\qquad \text { (NCT03113188) }\end{array}$ \\
\hline \multirow{3}{*}{ WEE1 } & \multirow{3}{*}{$\begin{array}{c}\text { Adavosertib/ } \\
\text { AZD1775/MK-1775 }\end{array}$} & I & $\begin{array}{l}\text { Advanced solid tumors (NCT01748825, NCT02610075, } \\
\text { NCT02482311, NCT03313557), recurrent GBM } \\
\text { (NCT02207010), with radiation and temozolomide in GBM } \\
\text { (NCT01849146), with olaparib in refractory solid tumors } \\
\text { (NCT02511795), with docetaxel and cisplatin before } \\
\text { surgery in NSCLC (NCT02508246), with cisplatin and } \\
\text { radiation in HNSCC (NCT03028766), radiation and } \\
\text { cisplatin in cervical, vaginal or uterine cancer } \\
\text { (NCT03345784), pharmacokinetic studies in solid tumors } \\
\text { (NCT03333824), with radiation in pontine gliomas in } \\
\text { pediatric patients (NCT01922076), with MEDI4736 in solid } \\
\text { tumors (NCT02617277), with irinotecan in RAS or BRAF } \\
\text { mutated colorectal cancer (NCT02906059), ovarian cancer } \\
\text { (NCT02659241), with MEDI4736 in bladder cancer } \\
\text { (NCT02546661) }\end{array}$ \\
\hline & & $\mathrm{I} / \mathrm{II}$ & $\begin{array}{l}\text { With gemcitabine (+Radiation) in pancreatic } \\
\text { adenocarcinoma (NCT02037230), with carboplatin in } \\
\text { refractory tumors (NCT02813135), with nab-paclitaxel and } \\
\text { gemcitabine in pancreatic cancer (NCT02194829), with } \\
\text { irinotecan in refractory solid tumors in younger patients } \\
\text { (NCT02095132) }\end{array}$ \\
\hline & & II & $\begin{array}{l}\text { Uterine serous carcinoma (NCT03668340), SCLC } \\
\text { (NCT02593019), in solid tumors with CCNE1 amplification } \\
\text { (NCT03253679), BRCA mutated tumors (NCT02465060), } \\
\text { with carboplatin and paclitaxel in squamous cell lung } \\
\text { cancer (NCT02513563), with concurrent radiation and } \\
\text { cisplatin in HNSCC (NCT02585973), with gemcitabine in } \\
\text { OPFTC (NCT02101775), with cisplatin in breast cancer } \\
\text { (NCT03012477), in AML, MDS and myelofibrosis } \\
\text { (NCT03718143), with chemotherapy in OPFTC } \\
\text { (NCT02272790), with olaparib in metastatic triple negative } \\
\text { breast cancer (NCT03330847), SETD2-deficient advanced } \\
\text { tumors (NCT03284385), with paclitaxel in advanced TP53 } \\
\text { mutated gastric cancer (NCT02448329), prostate cancer } \\
\text { (NCT03385655), with or without olaparib in recurrent } \\
\text { OPFTC (NCT03579316), with olaparib in advanced solid } \\
\text { tumors (NCT02576444), with carboplatin in advanced } \\
\text { solid tumors (NCT01827384), with carboplatin in extensive } \\
\text { SCLC (NCT02937818) }\end{array}$ \\
\hline
\end{tabular}


Table 2. Cont.

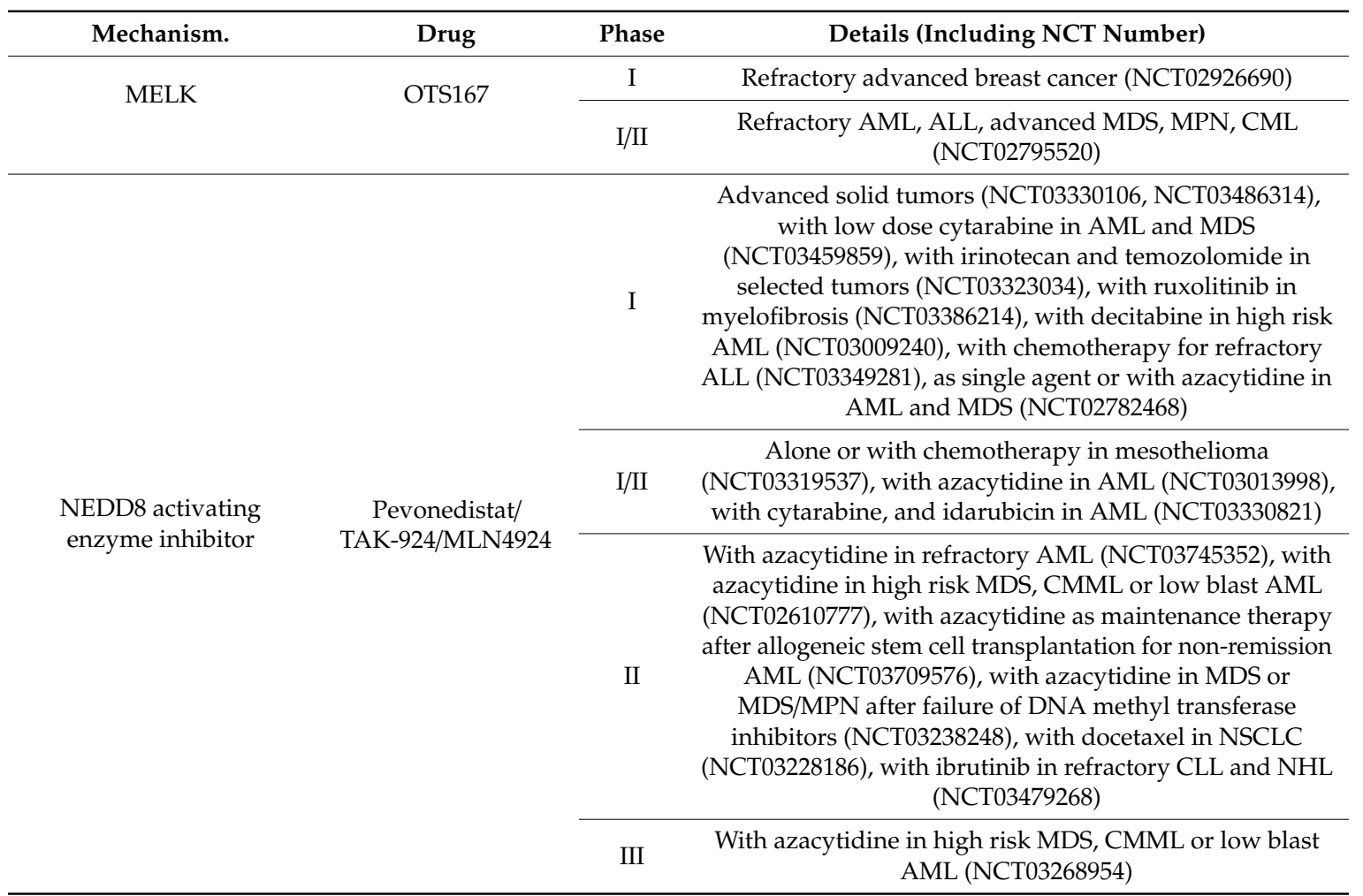

Data retrieved from: https://www.accessdata.fda.gov/scripts/cder/daf/ Retrieval date 04/21/2020 and https: //www.cancer.gov/about-cancer/treatment/drugs Retrieval date 04/21/2020. HNSCC—head and neck squamous cell carcinoma, WBRT-whole brain radiation therapy, NSCLC—non-small cell lung cancer, SCLC-small cell lung cancer, NET-neuroendocrine tumors, OPFTC-ovarian, primary peritoneal, or fallopian tube cancer, GEJ - gastroesophageal junction, PARPi-Poly (adenosine diphosphate ribose [ADP]-ribose) polymerase inhibitor, mCRPC-metastatic castration-resistant prostate cancer, CLL-chronic lymphocytic leukemia, PLL—prolymphocytic leukemia, NHL—non Hodgkin's lymphoma, HDR—homologous DNA repair, TNBC—triple negative breast cancer, AML—acute myelogenous leukemia, MDS—myelodysplastic syndrome, CMML—chronic myelomonocytic leukemia, MPN—myeloproliferative neoplasm, CLL—chronic lymphocytic leukemia, ALL—acute lymphoblastic leukemia.

Cancer cells can tolerate relatively elevated levels of replication stress because of a proficient response system that includes the ATR-Chk1 pathway [32]. The activation of ATK-Chk1 is crucial in suppressing further replicative stress and therefore helps cancer cells avoid deleterious events such as mitotic catastrophe. Inhibiting ATR or Chk1 can sensitize cancer cells to therapies harnessing replication stress and therefore combining ATR/Chk1 inhibitors to therapies inducing replication stress seems to be a logical approach [32].

Inhibition of the ATR/Chk1 pathway can induce synthetic lethality in cells with high levels of oncogene-induced replication stress such as cells with oncogenic Ras, APOBEC3A, or c-MYC overexpression as well as in cells deficient with p53, ATM, or POLD1 [33-38]. Synthetic lethality with ATR inhibitors has also been observed with AT-rich interaction domain 1A (ARID1A) mutant tumors, mutations causing accumulation of R loops (RNA-DNA hybrids) like U2AF1 (S34F) and with cancers overexpressing oncogenic SS18-SSX fusion proteins like synovial sarcoma [36,39-41].

Schisandrin B, a natural product, was the first ATR specific inhibitor, but the clinical application was restricted because of the requirement of a very high dose [42]. Though multiple agents are in preclinical development only a few agents namely VX-803 (M-4344), VX970 (berzosertib, M6620), AZD6738, BAY1895344 have reached clinical trials [43].

Chk1 also suppresses CDK activity through negative regulation of CDC25A phosphatase to manage precise activation of replication origins during $S$ phase $[44,45]$. As compared to ATR inhibition, Chk1 inhibition is more detrimental to cycling cells [46]. 
Development of Chk1 inhibitors have advanced further for multiple reasons including a wider, non-specific effect of ATR inhibition than Chk1 inhibition, difficulties with purification of active ATR protein and enzymatic analysis due to its large size and the lack of a crystallographic or cyro-EM structure and hence unawareness about possible allosteric binding sites for drug design and lack of standardized high throughput assays for analysis of ATR inhibitors [47-50].

UCN-01 (7-hydroxystaurosporine) was the first Chk1 inhibitor. The development of which hit roadblocks because of the lack of specificity and unusual pharmacokinetic features including low distribution volume, systemic clearance, and long elimination half-life ( $>200 \mathrm{~h}$ ), likely due to high affinity to $\alpha-1$ acid glycoprotein [51,52]. Thereafter, multiple other agents including XL844, CBP501, AZD7762, LY2603618, MK-8776 (SCH 900776), PF-00477736, LY2606368 (Prexasertib) reached clinical trials but are yet to show valuable activity and efficacy [52].

\subsubsection{PARP Inhibitors}

Poly ADP-ribose polymerase (PARP) family comprises 18 enzymes, amongst them, PARP1 is the most well studied [3,53]. PARP1 is a major component of DNA damage repair pathway and its role in DNA repair has been covered in detail in an excellent review by Ray Chaudhuri and André Nussenzweig [53]. In brief, PARP1 activates SSB repair, is involved in ssDNA nick repairs, promotes nucleotide excision repair, acts as a sensor of dsDNA breaks, and modulates chromatin structure in response to DNA damage [53]. It is also involved in the HR and NHEJ pathways [53]. It recruits MRE11 to initiate the end processing required for replication restart and is also implicated in the recruitment of other HR proteins [53]. PARP1 has been shown to be involved in the recruitment of DNA repair and checkpoint proteins at sites of DNA damage, enhancing Chk1 activation and its binding at stalled replication forks, which is required for replication restart [54-56]. It also regulates the rate of DNA replication fork progression during DNA replication stress and its inhibition during replication stress leads to abrogation of fork slowdown [53]. Therefore, inhibition of PARP1 increases replication stress [3].

However, even though high PARP-1 expression is observed in many tumors [57], its inhibition alone has limited efficacy [58]. But it becomes lethal to tumors with a defect in DNA repair pathway as seen in breast cancer gene (BRCA)-deficient tumors [58]. BRCA1 and BRCA2 proteins are essential for the repair of dsDNA breaks via HR repair, and cells with deficient or altered HR repair pathway depend on non-conservative forms of DNA repair like inaccurate NHEJ [58].

Deficiency of genes involved in HR repair pathways like RAD51, RAD54, DSS1, RPA1, NBS1, ATR, ATM, Chk1, Chk2, FANCD2, FANCA, or FANCC also induce sensitivity to PARP inhibitors [59]. This provides a potentially unique opportunity for PARP therapies in cancers with loss-of-function mutations in these genes.

Sporadic tumors might also develop a phenocopy of BRCA1 or BRCA2 mutation where HR repair defects exist in tumor because of other reasons like BRCA1 promoter hypermethylation, amplification of EMSY etc., without germline BRCA1 or BRCA2 mutation, a phenomenon known as BRCAness [60]. PARP inhibitors might also provide a rational approach to target the tumors with BRCAness [60].

This synthetic lethality with PARP1 inhibitors in BRCA or HR-deficient tumors is thought to be due to various reasons. First, if ssDNA breaks are persistent, they will convert to DSB and eventually need DSB repair (HR and NHEJ) pathways. Therefore, BRCA or HR-deficient cancer cells need NHEJ for DSB repair which is PARP1 dependent and its inhibition can drive them toward apoptosis [61,62]. Second, both BRCA2 and PARP1 prevent Mre11-dependent degradation of stalled replication forks [63]. Actually, BRCA1, BRCA2, PARP1, and PARP2 all prevent or mediate stalled folk degradation [64,65]. Third, PARP inhibitors trap PARP1 and PARP2 enzymes at damaged DNA site which obstructs other DNA repair proteins [66]. Fourth, inhibiting PARP during replicative stress makes cells depend on HR for DNA repair and leads to synthetic lethality in BRCA or HR-deficient tumors [3,61].

Nicotinamide was the first known naturally occurring PARP inhibitor and 3-aminobenzamide was the first synthetic PARP inhibitor $[67,68]$. Iniparib (BSI-201) was the first PARP inhibitor to reach phase 
III trial but failed to meet its primary endpoint [69]. Thereafter multiple PARP inhibitors including olaparib, rucaparib, niraparib, veliparib, and talazoparib have reached clinical trials and four of this niraparib, rucaparib, Olaparib, and talazoparib have received FDA approval (Table 1) [58].

PARPs (in particular PARP1), along with RECQ-like (RECQL) helicases, including RECQL1, WRN, BLM, RECQL4, and RECQL5, represent two central quality control systems to preserve genome integrity in mammalian cells. Both are involved in the control of DNA repair, telomere maintenance, and replicative stress [70]. RECQL1, which is first discovered, provides several potential functional overlaps with PARP1 and other RECQL helicases due to its involvement in replication, DNA repair, and telomere maintenance [71]. WRN, which is also called RECQL2, is revealed to have functional and biochemical relevant interactions with PARP1 on a biochemical, cellular, and organismal level [70]. BLM, also known as RECQL3, plays important roles in HR where it is involved in DNA end-resection as well as in the subsequent branch migration and resolution of Holliday junctions (HJ) or double $\mathrm{HJ}(\mathrm{dHJ})$, which may contribute to HR fidelity and suppresses crossover reactions [72,73]. As all five RECQL helicases physically or functionally interact with PARP1 and/or its enzymatic product poly (ADP-ribose) (PAR), the cooperative function of RECQLs and PARP1 is crucial to maintaining genome integrity. In fact, RECQ1 is found to be required for cellular resistance to replication stress [74], and loss-of-function mutations in the RECQ1 gene are associated with increased susceptibility to breast cancer [75], as well as enhanced sensitivity to DNA damaging agents [76].

Other PARP members, such as PARP10, were recently found to be overexpressed in various tumors and promote cellular proliferation [77]. Its overexpression alleviates replication stress and is suggested to promote the restart of replication forks [77]. PARP10 can be another novel target to further enhance DNA replicative stress for cancer therapies.

\subsubsection{Other Targets That Are Relevant to DNA Replication Stress}

Overexpression and upregulation of HR proteins like RAD51 are commonly encountered in malignant cells [78]. RAD51 is involved in HR-mediated repair of DSBs and promotion of replication fork stability during replication stress and therefore can contribute to tumor resistance to DNA-damaging therapies [78]. Therefore, targeting proteins involved in HR repair like RAD51 seems promising for future investigations [78,79]. RAD51 inactivation appeared to increase ATR/Chk1-mediated replication signaling and inhibition of ATR or Chk1 in this scenario can provide another opportunity for exploring synthetic lethality [80].

Many cancer cells appear to depend on constitutive hyper-signaling of ATR to upregulate HR proteins to overcome replication stress. Chronic long-term inhibition of ATR signaling can severely impair homologous recombination (HR)-mediated DNA repair and abundance of HR proteins in cancer cells [81]. This can mimic "BRCAness" and can sensitize HR-proficient cancer cells to PARP inhibitors after chronic treatment which can provide a basis for the synergistic combination of ATR and PARP inhibitors in this setting [81].

Cyclin-dependent kinase 12 (CDK12) is a member of cyclin-dependent kinase (CDK) family of serine/threonine protein kinases which can regulate transcriptional and post-transcriptional processes, and therefore modulate multiple cellular functions [82]. CDK12 upregulates genes involved in the response to DNA damage and stress. Mutations in CDK12 gene have been observed in multiple cancer types [82]. CDK12 inhibition is predicted to not only inhibit tumor growth but can lead to synthetic lethality with MYC, EWS/FL1, and PARP/Chk1 inhibition [82].

Tousled-like kinases 1 and 2 (TLK1/TLK2) are nuclear serine/threonine kinases which are regulated by Chk1 [83]. TLK1/2 are required for DNA replication and replication-coupled nucleosome assembly [84]. Their inhibition can lead to the stalling of the replication forks and ssDNA accumulation, ultimately leading to increased replication stress [84]. In fact, depletion of TLKs was found synthetic lethal with checkpoint inactivation and PARP inhibitors [84].

WEE1 is a nuclear serine/threonine kinase that inhibits CDK1 and 2 which activates G2/M cell cycle checkpoint leading to the inhibition of cell entry into mitosis [85]. WEE1 inhibition leads to enhancement 
of CDK activity causing unscheduled entry into M phase even if DNA replication is incomplete or defective, causing unchecked firing of replication origins, nucleotide shortage translating into increased replication stress, and death from mitotic catastrophe [3,85,86]. Currently, adavosertib (AZD1775, MK-1775) is the only WEE1 inhibitor undergoing clinical development [86]. Maternal embryonic leucine zipper kinase (MELK), a serine/threonine protein kinase that belongs to the sub-family of AMP-activated serine/threonine protein kinases, has appeared as a target for decreasing replication stress threshold [87]. MELK plays a major role in various cellular and biological processes including DNA repair [88]. OTS167 is a MELK inhibitor which is currently undergoing clinical development (NCT02926690, NCT01910545, NCT02795520). However, the role of MELK as a cancer target is currently controversial [89].

Neddylation, a ubiquitin-like modification can reduce replication stress [90]. NEDD8 is one of the most studied ubiquitin-like protein which plays a critical role in mediating the ubiquitination of numerous cullin-RING ligases substrate proteins involved in cell cycle progression and survival [91]. Inhibition of neddylation leads to the stabilization of the substrates of these ubiquitin ligases including DNA replication factor CDT1, which forms a complex with the replication-licensing factor geminin, causing DNA to replicate more than once per S phase, therefore rapidly consuming dNTP $[92,93]$. Depleting CDT1 inhibitor geminin can increase origin firing to induce re-replication in cancer cells leading to DNA damage and apoptosis [7]. Pevonedistat (TAK-924/MLN4924) is a novel inhibitor of NEDD8-activating enzyme currently undergoing multiple phase I/II trials (Table 2). It causes CDT1 stabilization, re-replication, senescence, and apoptosis in cancer cells [93]. TAS4464, another highly potent NEDD8-activating enzyme inhibitor, underwent a phase I/II study in multiple myeloma and lymphoma but the study has been terminated due to business reasons (NCT02978235).

Apart from ATR/Chk1 pathway, ATM/Chk2 and DNA-PK pathways are also activated during DNA replication stress likely because of secondary DSBs and obstructing these pathways with inhibitors of ATM, Chk2, DNA-PK, and their downstream proteins can potentiate replication stress $[94,95]$.

\section{Potential Combination Treatment Approaches}

Replication stress pathway includes a concoction of multiple checkpoints and proteins that are exploited in unique ways by various agents discussed above to target cancer cells. Therefore, a combination approach of these agents appears to be an attractive option. For the last many years combination of chemotherapy with radiation has been considered the standard of care in neoadjuvant and adjuvant settings as well as part of definitive treatment for many cancers [96-98]. Similarly, combination chemotherapies, as well as chemoimmunotherapy combinations, have received approval for various cancers $[99,100]$. Combining immunotherapies with agents targeting DNA repair like ATM, ATR, or DNA-PK inhibitors or PARP inhibitors present attractive options for combination therapies in selected cancers [101]. In fact, many clinical trials are currently in progress with these combinations [101].

The ATR-Chk1 pathway is activated by ssDNA and plays an important role in controlling replicative stress [3]. ATR inhibitors show enhanced activity with molecules capable of inducing replication stress [30] like inter-strand cross-linking agents (mitomycin C, cisplatin, carboplatin), nucleoside analogs (gemcitabine, cytarabine), PARP inhibitors and topoisomerase inhibitors (irinotecan, etoposide) in various cancer cell lines [30]. ATR inhibitors have a radiosensitizing effect which is more modest when compared to chemosensitizing agents [30,52]. ATR and PARP inhibition induces specific cytotoxicity in GBM cancer stem-like cells and negates radiation resistance [102]. ATR inhibitors have shown synergy with agents forcing premature mitotic entry like WEE1 inhibitors in mouse embryonic stem cells [103] and Chk1 inhibitors by further suppression of replication stress [30]. ATR inhibitors have also been shown to synergize with insulin-like growth factor 1 receptor tyrosine kinase inhibitor in breast cancer cell lines [104] and bromodomain and extra-terminal (BET) family inhibitors in melanoma and MYC-induced lymphoma $[30,105,106]$. 
PARP inhibitors have also shown synergy with radiation, various chemotherapies like alkylating agents, topoisomerase inhibitors, platinum compounds, EGFR-directed therapies, anti-vascular endothelial growth factor therapies, and PI3K inhibitors $[3,57,58]$. Similarly, WEE1 inhibitors have shown synthetic lethality with Chk1 inhibitors and in H3K36me3-deficient cancers [107,108]. WEE1 inhibitors are also predicted to be synthetically lethal in cells with defects in Fanconi Anemia and HR pathways [109]. Preclinical studies have shown synergy between WEE1 and PARP inhibitors in small-cell lung cancer [110].

Cisplatin has shown synergy with Chk1 and WEE1 inhibitors in preclinical models $[85,111]$. Gemcitabine has shown synergy with ATR, Chk1, WEE1, and NEDD8-activating enzyme inhibitors in preclinical models [112-115] but unexpected cardiotoxicity with Chk1 inhibitor AZD7762 in clinical trials [116,117]. Therefore, even though we have multiple combinations which have shown synergism or synthetic lethality in preclinical models, these novel combinations need careful evaluation in clinical setting due to unexpected toxicities.

In the era of cancer immunotherapy, it is very important to understand whether we can take advantage of DNA replicative stress to further enhance immunotherapy. It is known that DSBs can upregulate PD-L1 expression in cancer cells [118]. This upregulation requires ATM/ATR/Chk1 kinases and is augmented after DSBs when a specific DSB repair protein, BRCA2 or Ku70/80 is depleted [118]. Pembrolizumab, an anti PD-1 immunotherapy has been approved in unresectable or metastatic, microsatellite instability-high or mismatch repair deficient tumors [119]. In fact, defects in DNA repair such as DDR deficiency lead to genomic instability, higher tumor immunogenicity, greater mutational and neoantigen burden which leads to an improved response to immunotherapy [101]. Therefore, immunotherapy may prove to be beneficial in combination with agents modulating replication stress to treat cancer. However, caution needs to be taken as an intact DDR plays an important role in immunity [120], and therefore the optimal combination with various immunotherapy needs to be further determined [121].

\section{Future Directions, Identification of Biomarkers and Resistance Mechanisms}

Even though we have come a long way in understanding replication stress and a great deal of effort is being undertaken in harnessing it for cancer treatment, we have met with limited success. Therefore, there is a need to look beyond the conventional approaches. Further investigations need to be done to potentiate replication stress by combining it with other traditional pathways. It is well-known that cancer cells are in oxidative stress [122] and increasing reactive oxygen species levels can further enhance replicative stress due to the incorporation of oxidized nucleotides [122,123]. This approach can selectively target cancer cells, due to them being in a perennial prooxidative state as compared to normal cells [122]. It is also hypothesized that increasing reactive oxygen species in cancer stem cells may make them more radiosensitive [124]. Targeting chromatin with agents like histone deacetylase inhibitors increases replicative stress [125-127]. Moreover, synergism has been observed between histone deacetylase and WEE1 inhibitors [128]. This provides another rational combination to target replication stress. Other potential approaches include modulating cell death pathways like apoptosis, senescence, and autophagy as they all induce profound replication stress [3,129-131]. Theoretically, enhancing G1-S transition can also potentiate DNA replication stress as replication stress is only possible during DNA synthesis (S phase) but on the downside can lead to enhanced tumor growth too $[3,7,132]$. Incorporating damaged dNTPs in cancer cells has been suggested as a strategy to increase replication stress by targeting NUDT1 (MTH1), which prevents misincorporation of oxidized dNTPs during replication $[7,133,134]$. Other alternatives include depleting licensing factors like ORC1 to sensitize tumor cells to hydroxyurea and $\mathrm{H}_{2} \mathrm{O}_{2}[7,135]$. Similar result was also observed following CDC6 depletion in KRAS positive cancer cells [136].

For successful targeting of replication stress, there is an urgent need for a set of biomarkers which cannot only provide an accurate and precise quantification of replication stress in cancer cells but can also be used for modulating treatment and guiding diagnosis, treatment, and prognosis. Advancements 
have been made in identifying patients for precision medicine treatment like BRCA mutations for PARP inhibitors [69]. With regards to measuring replication stress, possible biomarkers include measurement of proteins bound to stalled replication fork by immunofluorescence analysis $(\gamma \mathrm{H} 2 \mathrm{AX}$, FANCD2, RPA etc.), DNA fiber assays for stalled replication fork, karyotype analysis, lagging DNA, ultra-fine anaphase DNA bridge analysis, micronuclei analysis, whole genome sequencing, SNP array analysis, microarray analysis, immunohistochemical analysis of proteins involved in replication stress or chromosome instability, chromatin immunoprecipitation for DNA replication and repair factors, bromodeoxyuridine staining for detection of ssDNA accumulation etc., [137-139]. Some of these novel methods can be utilized only in preclinical settings to evaluate the effectiveness of potential strategies in modulating replication stress, while others can be used on patient samples after validation [137]. However, the major need is for biomarkers that can monitor these effects in a non-invasive, cost-effective manner from peripheral blood in real-time. Current methods like immunohistochemical analysis of $\gamma \mathrm{H} 2 \mathrm{AX}$ do not differentiate replicative stress from general DNA damage, and apoptosis as measured by cleaved caspase or TUNEL which may reflect only the downstream consequences of replicative stress [3].

Another field of investigation is understanding the mechanisms of resistance to these novel agents. A prime example includes PARP inhibitors where multiple resistance mechanisms have been identified. These include restoration of BRCA1/2 function via secondary mutations [140], restoration of HR through somatic loss of NHEJ factor 53BP1 [141], decreased PARP expression levels [58], increased RAD51 activity [142], restoration of fork protection [143], and upregulation of ATP-binding cassette $(\mathrm{ABC})$ transporters such as p-glycoprotein efflux pump and resultant higher rate of drug efflux [144]. To overcome these resistance mechanisms, the next generation of PARP inhibitors like AZD2461, which are poor substrates for drug transporters, are in development [145]. Other potential mechanisms to overcome resistance include employing inhibitors of multidrug resistance pumps like verapamil [146] and tariquidar [144]. Similar investigations are ongoing with ATR, Chk1, and Wee1 inhibitors $[103,147]$.

\section{Conclusions}

In this review, we discuss current approaches to utilize DNA replication stress, along with underlying mechanisms and future directions. As we understand more about DDR pathways and cancer genomics, replication stress, and its modulation in cancer will be a major field of investigation and may help pave the way toward the personalized medicine in clinical practice. Multiple novel therapies targeting replication stress are in development and these novel molecules and biomarkers have the potential to advance the field with exciting impact on cancer treatment. The need will be to put them in the correct scenarios and understand the resistance mechanisms.

Author Contributions: H.Z., U.S., R.P., and J.Z. wrote the manuscript. All authors have read and agreed to the published version of the manuscript.

Funding: This research received no external funding.

Acknowledgments: This work was supported by the University of Kansas Start-up Funds, KUCC Pilot Award, as well as the "Play with a Pro" Lung Cancer Research Fund (J.Z.).

Conflicts of Interest: The authors declare that they have no competing interests. J.Z. received research support from Genentech, Novartis, Mirati, Abbvie, and Hengrui. J.Z. is also on the advisory board of AstraZeneca and Biodesix.

\section{References}

1. Fragkos, M.; Ganier, O.; Coulombe, P.; Mechali, M. DNA replication origin activation in space and time. Nat. Rev. Mol. Cell Biol. 2015, 16, 360-374. [CrossRef] [PubMed]

2. Pearl, L.H.; Schierz, A.C.; Ward, S.E.; Al-Lazikani, B.; Pearl, F.M. Therapeutic opportunities within the DNA damage response. Nat. Rev. Cancer 2015, 15, 166-180. [CrossRef] [PubMed] 
3. Zhang, J.; Dai, Q.; Park, D.; Deng, X. Targeting DNA Replication Stress for Cancer Therapy. Genes 2016, 7, 51. [CrossRef] [PubMed]

4. Chatterjee, N.; Walker, G.C. Mechanisms of DNA damage, repair, and mutagenesis. Environ. Mol. Mutagen. 2017, 58, 235-263. [CrossRef]

5. Shah, A.P.; Patel, C.N.; Sureja, D.K.; Sanghavi, K.P. A Review on DNA Repair Inhibition by PARP Inhibitors in Cancer Therapy. Folia Med. 2018, 60, 39-47. [CrossRef]

6. Berti, M.; Vindigni, A. Replication stress: Getting back on track. Nat. Struct. Mol. Biol. 2016, 23, $103-109$. [CrossRef]

7. Gaillard, H.; Garcia-Muse, T.; Aguilera, A. Replication stress and cancer. Nat. Rev. Cancer 2015, 15, $276-289$. [CrossRef]

8. Forment, J.V.; O'Connor, M.J. Targeting the replication stress response in cancer. Pharmacol. Ther. 2018, 188, 155-167. [CrossRef]

9. Zeman, M.K.; Cimprich, K.A. Causes and consequences of replication stress. Nat. Cell Biol. 2014, 16, 2-9. [CrossRef]

10. Eykelenboom, J.K.; Harte, E.C.; Canavan, L.; Pastor-Peidro, A.; Calvo-Asensio, I.; Llorens-Agost, M. ATR activates the S-M checkpoint during unperturbed growth to ensure sufficient replication prior to mitotic onset. Cell Rep. 2013, 5, 1095-1107. [CrossRef]

11. Toledo, L.I.; Altmeyer, M.; Rask, M.B.; Lukas, C.; Larsen, D.H.; Povlsen, L.K.; Bekker-Jensen, S.; Mailand, N.; Bartek, J.; Lukas, J. ATR prohibits replication catastrophe by preventing global exhaustion of RPA. Cell 2013, 155, 1088-1103. [CrossRef] [PubMed]

12. Toledo, L.; Neelsen, K.J.; Lukas, J. Replication Catastrophe: When a Checkpoint Fails because of Exhaustion. Mol. Cell 2017, 66, 735-749. [CrossRef] [PubMed]

13. Toledo, L.I.; Murga, M.; Zur, R.; Soria, R.; Rodriguez, A.; Martinez, S.; Oyarzabal, J.; Pastor, J.; Bischoff, J.R.; Fernandez-Capetillo, O. A cell-based screen identifies ATR inhibitors with synthetic lethal properties for cancer-associated mutations. Nat. Struct. Mol. Biol. 2011, 18, 721-727. [CrossRef] [PubMed]

14. Canman, C.E. Replication checkpoint: Preventing mitotic catastrophe. Curr. Biol. 2001, 11, R121-R124. [CrossRef]

15. Lecona, E.; Fernandez-Capetillo, O. Replication stress and cancer: It takes two to tango. Exp. Cell Res. 2014, 329, 26-34. [CrossRef]

16. Hanahan, D.; Weinberg, R.A. Hallmarks of cancer: The next generation. Cell 2011, 144, 646-674. [CrossRef]

17. Morgan, M.A.; Lawrence, T.S. Molecular Pathways: Overcoming Radiation Resistance by Targeting DNA Damage Response Pathways. Clin. Cancer Res. 2015, 21, 2898-2904. [CrossRef]

18. Fu, D.; Calvo, J.A.; Samson, L.D. Balancing repair and tolerance of DNA damage caused by alkylating agents. Nat. Rev. Cancer 2012, 12, 104-120. [CrossRef]

19. Wang, D.; Lippard, S.J. Cellular processing of platinum anticancer drugs. Nat. Rev. Drug Discov. 2005, 4, 307-320. [CrossRef]

20. Deans, A.J.; West, S.C. DNA interstrand crosslink repair and cancer. Nat. Rev. Cancer. 2011, 11, 467-480. [CrossRef]

21. Sale, J.E.; Lehmann, A.R.; Woodgate, R. Y-family DNA polymerases and their role in tolerance of cellular DNA damage. Nat. Rev. Mol. Cell Biol. 2012, 13, 141-152. [CrossRef]

22. Kotsantis, P.; Jones, R.M.; Higgs, M.R.; Petermann, E. Cancer therapy and replication stress: Forks on the road to perdition. Adv. Clin. Chem. 2015, 69, 91-138. [PubMed]

23. Ewald, B.; Sampath, D.; Plunkett, W. Nucleoside analogs: Molecular mechanisms signaling cell death. Oncogene 2008, 27, 6522-6537. [CrossRef] [PubMed]

24. Longley, D.B.; Harkin, P.D.; Johnston, G.P. 5-fluorouracil: Mechanisms of action and clinical strategies. Nat. Rev. Cancer 2003, 3, 330-338. [CrossRef] [PubMed]

25. Delgado, J.L.; Hsieh, C.M.; Chan, N.L.; Hiasa, H. Topoisomerases as anticancer targets. Biochem. J. 2018, 475, 373-398. [CrossRef] [PubMed]

26. Regairaz, M.; Zhang, Y.W.; Fu, H.; Agama, K.K.; Tata, N.; Agrawal, S.; Aladjem, M.I.; Pommier, Y. Mus81-mediated DNA cleavage resolves replication forks stalled by topoisomerase I-DNA complexes. J. Cell Biol. 2011, 195, 739-749. [CrossRef] [PubMed] 
27. Seiler, J.A.; Conti, C.; Syed, A.; Aladjem, M.I.; Pommier, Y. The intra-S-phase checkpoint affects both DNA replication initiation and elongation: Single-cell and -DNA fiber analyses. Mol. Cell Biol. 2007, 27, 5806-5818. [CrossRef]

28. Ray Chaudhuri, A.; Hashimoto, Y.; Herrador, R.; Neelsen, K.J.; Fachinetti, D.; Bermejo, R.; Cocito, A.; Costanzo, V.; Lopes, M. Topoisomerase I poisoning results in PARP-mediated replication fork reversal. Nat. Struct. Mol. Biol. 2012, 19, 417-423. [CrossRef]

29. Loegering, D.; Arlander, S.J.; Hackbarth, J.; Vroman, B.T.; Roos-Mattjus, P.; Hopkins, K.M.; Lieberman, H.B.; Karnitz, L.M.; Kaufmann, S.H. Rad9 protects cells from topoisomerase poison-induced cell death. J. Biol. Chem. 2004, 279, 18641-18647. [CrossRef]

30. Lecona, E.; Fernandez-Capetillo, O. Targeting ATR in cancer. Nat. Rev. Cancer 2018, 18, 586-595. [CrossRef]

31. Blackford, A.N.; Jackson, S.P. ATM, ATR, and DNA-PK: The Trinity at the Heart of the DNA Damage Response. Mol. Cell 2017, 66, 801-817. [CrossRef] [PubMed]

32. Saldivar, J.C.; Cortez, D.; Cimprich, K.A. The essential kinase ATR: Ensuring faithful duplication of a challenging genome. Nat. Rev. Mol. Cell Biol. 2017, 18, 622-636. [CrossRef] [PubMed]

33. Salovska, B.; Janeckova, H.; Fabrik, I.; Karlikova, R.; Cechakova, L.; Ondrej, M.; Link, M.; Friedecky, D.; Tichy, A. Radio-sensitizing effects of VE-821 and beyond: Distinct phosphoproteomic and metabolomic changes after ATR inhibition in irradiated MOLT-4 cells. PLoS ONE 2018, 13, e0199349. [CrossRef] [PubMed]

34. Gilad, O.; Nabet, B.Y.; Ragland, R.L.; Schoppy, D.W.; Smith, K.D.; Durham, A.C.; Brown, E.J. Combining ATR suppression with oncogenic Ras synergistically increases genomic instability, causing synthetic lethality or tumorigenesis in a dosage-dependent manner. Cancer Res. 2010, 70, 9693-9702. [CrossRef]

35. Buisson, R.; Lawrence, M.S.; Benes, C.H.; Zou, L. APOBEC3A and APOBEC3B Activities Render Cancer Cells Susceptible to ATR Inhibition. Cancer Res. 2017, 77, 4567-4578. [CrossRef]

36. Kantidze, O.L.; Velichko, A.K.; Luzhin, A.V.; Petrova, N.V.; Razin, S.V. Synthetically Lethal Interactions of ATM, ATR, and DNA-PKcs. Trends Cancer 2018, 4, 755-768. [CrossRef]

37. Murga, M.; Campaner, S.; Lopez-Contreras, A.J.; Toledo, L.I.; Soria, R.; Montana, M.F.; Artista, L.; Schleker, T.; Guerra, C.; Garcia, E.; et al. Exploiting oncogene-induced replicative stress for the selective killing of Myc-driven tumors. Nat. Struct. Mol. Biol. 2011, 18, 1331-1335. [CrossRef]

38. Hocke, S.; Guo, Y.; Job, A.; Orth, M.; Ziesch, A.; Lauber, K.; de Toni, E.N.; Gress, T.M.; Herbst, A.; Goke, B.; et al. A synthetic lethal screen identifies ATR-inhibition as a novel therapeutic approach for POLD1-deficient cancers. Oncotarget 2016, 7, 7080-7095. [CrossRef]

39. Williamson, C.T.; Miller, R.; Pemberton, H.N.; Jones, S.E.; Campbell, J.; Konde, A.; Badham, N.; Rafiq, R.; Brough, R.; Gulati, A.; et al. ATR inhibitors as a synthetic lethal therapy for tumours deficient in ARID1A. Nat. Commun. 2016, 7, 13837. [CrossRef]

40. Nguyen, H.D.; Leong, W.Y.; Li, W.; Reddy, P.N.G.; Sullivan, J.D.; Walter, M.J.; Zou, L.; Graubert, T.A. Spliceosome Mutations Induce R Loop-Associated Sensitivity to ATR Inhibition in Myelodysplastic Syndromes. Cancer Res. 2018, 78, 5363-5374. [CrossRef]

41. Jones, S.E.; Fleuren, E.D.G.; Frankum, J.; Konde, A.; Williamson, C.T.; Krastev, D.B.; Pemberton, H.N.; Campbell, J.; Gulati, A.; Elliott, R.; et al. ATR Is a Therapeutic Target in Synovial Sarcoma. Cancer Res. 2017, 77, 7014-7026. [CrossRef] [PubMed]

42. Nishida, H.; Tatewaki, N.; Nakajima, Y.; Magara, T.; Ko, K.M.; Hamamori, Y.; Konishi, T. Inhibition of ATR protein kinase activity by schisandrin B in DNA damage response. Nucleic Acids Res. 2009, 37, 5678-5689. [CrossRef] [PubMed]

43. United States National Library of Medicine at National Institutes of Health. Available online: https: //clinicaltrials.gov (accessed on 26 August 2018).

44. Zhao, H.; Watkins, J.L.; Piwnica-Worms, H. Disruption of the checkpoint kinase 1/cell division cycle 25A pathway abrogates ionizing radiation-induced S and G2 checkpoints. Proc. Natl. Acad. Sci. USA 2002, 99, 14795-14800. [CrossRef] [PubMed]

45. Hauge, S.; Naucke, C.; Hasvold, G.; Joel, M.; Rodland, G.E.; Juzenas, P.; Stokke, T.; Syljuasen, R.G. Combined inhibition of Wee1 and Chk1 gives synergistic DNA damage in S-phase due to distinct regulation of CDK activity and CDC45 loading. Oncotarget 2017, 8, 10966-10979. [CrossRef] [PubMed]

46. Buisson, R.; Boisvert, J.L.; Benes, C.H.; Zou, L. Distinct but Concerted Roles of ATR, DNA-PK, and Chk1 in Countering Replication Stress during S Phase. Mol. Cell. 2015, 59, 1011-1024. [CrossRef] 
47. Fokas, E.; Prevo, R.; Hammond, E.M.; Brunner, T.B.; McKenna, W.G.; Muschel, R.J. Targeting ATR in DNA damage response and cancer therapeutics. Cancer Treat. Rev. 2014, 40, 109-117. [CrossRef]

48. Brown, E.J.; Baltimore, D. ATR disruption leads to chromosomal fragmentation and early embryonic lethality. Genes Dev. 2000, 14, 397-402.

49. De Klein, A.; Muijtjens, M.; van Os, R.; Verhoeven, Y.; Smit, B.; Carr, A.M.; Lehmann, A.R. Targeted disruption of the cell-cycle checkpoint gene ATR leads to early embryonic lethality in mice. Curr. Biol. 2000, 10, 479-482. [CrossRef]

50. Fang, B. Development of synthetic lethality anticancer therapeutics. J. Med. Chem. 2014, 57, 7859-7873. [CrossRef]

51. Fuse, E.; Tanii, H.; Kurata, N.; Kobayashi, H.; Shimada, Y.; Tamura, T.; Sasaki, Y.; Tanigawara, Y.; Lush, R.D.; Headlee, D.; et al. Unpredicted clinical pharmacology of UCN-01 caused by specific binding to human alpha1-acid glycoprotein. Cancer Res. 1998, 58, 3248-3253.

52. Qiu, Z.; Oleinick, N.L.; Zhang, J. ATR/CHK1 inhibitors and cancer therapy. Radiother. Oncol. 2018, 126, 450-464. [CrossRef] [PubMed]

53. Ray Chaudhuri, A.; Nussenzweig, A. The multifaceted roles of PARP1 in DNA repair and chromatin remodelling. Nat. Rev. Mol. Cell Biol. 2017, 18, 610-621. [CrossRef] [PubMed]

54. Ahel, I.; Ahel, D.; Matsusaka, T.; Clark, A.J.; Pines, J.; Boulton, S.J.; West, S.C. Poly(ADP-ribose)-binding zinc finger motifs in DNA repair/checkpoint proteins. Nature 2008, 451, 81-85. [CrossRef] [PubMed]

55. Bryant, H.E.; Petermann, E.; Schultz, N.; Jemth, A.S.; Loseva, O.; Issaeva, N.; Johansson, F.; Fernandez, S.; McGlynn, P.; Helleday, T. PARP is activated at stalled forks to mediate Mre11-dependent replication restart and recombination. EMBO J. 2009, 28, 2601-2615. [CrossRef] [PubMed]

56. Min, W.; Bruhn, C.; Grigaravicius, P.; Zhou, Z.W.; Li, F.; Kruger, A.; Siddeek, B.; Greulich, K.O.; Popp, O.; Meisezahl, C.; et al. Poly(ADP-ribose) binding to Chk1 at stalled replication forks is required for S-phase checkpoint activation. Nat. Commun. 2013, 4, 2993. [CrossRef] [PubMed]

57. Benafif, S.; Hall, M. An update on PARP inhibitors for the treatment of cancer. Onco. Targets Ther. $2015,8,519$.

58. Ohmoto, A.; Yachida, S. Current status of poly(ADP-ribose) polymerase inhibitors and future directions. Onco. Targets Ther. 2017, 10, 5195-5208. [CrossRef]

59. McCabe, N.; Turner, N.C.; Lord, C.J.; Kluzek, K.; Bialkowska, A.; Swift, S.; Giavara, S.; O'Connor, M.J.; Tutt, A.N.; Zdzienicka, M.Z.; et al. Deficiency in the repair of DNA damage by homologous recombination and sensitivity to poly(ADP-ribose) polymerase inhibition. Cancer Res. 2006, 66, 8109-8115. [CrossRef]

60. Lord, C.J.; Ashworth, A. BRCAness revisited. Nat. Rev. Cancer 2016, 16, 110-120. [CrossRef]

61. Liu, C.; Srihari, S.; Cao, K.A.; Chenevix-Trench, G.; Simpson, P.T.; Ragan, M.A.; Khanna, K.K. A fine-scale dissection of the DNA double-strand break repair machinery and its implications for breast cancer therapy. Nucleic Acids Res. 2014, 42, 6106-6127. [CrossRef]

62. Wang, M.; Wu, W.; Wu, W.; Rosidi, B.; Zhang, L.; Wang, H.; Iliakis, G. PARP-1 and Ku compete for repair of DNA double strand breaks by distinct NHEJ pathways. Nucleic Acids Res. 2006, 34, 6170-6182. [CrossRef] [PubMed]

63. Ying, S.; Hamdy, F.C.; Helleday, T. Mre11-dependent degradation of stalled DNA replication forks is prevented by BRCA2 and PARP1. Cancer Res. 2012, 72, 2814-2821. [CrossRef] [PubMed]

64. Liao, H.; Ji, F.; Helleday, T.; Ying, S. Mechanisms for stalled replication fork stabilization: New targets for synthetic lethality strategies in cancer treatments. EMBO Rep. 2018, 19, e46263. [CrossRef]

65. Ronson, G.E.; Piberger, A.L.; Higgs, M.R.; Olsen, A.L.; Stewart, G.S.; McHugh, P.J.; Petermann, E.; Lakin, N.D. PARP1 and PARP2 stabilise replication forks at base excision repair intermediates through Fbh1-dependent Rad51 regulation. Nat. Commun. 2018, 9, 746. [CrossRef] [PubMed]

66. Murai, J.; Huang, S.Y.; Das, B.B.; Renaud, A.; Zhang, Y.; Doroshow, J.H.; Ji, J.; Takeda, S.; Pommier, Y. Trapping of PARP1 and PARP2 by Clinical PARP Inhibitors. Cancer Res. 2012, 72, 5588-5599. [CrossRef] [PubMed]

67. Rankin, P.W.; Jacobson, E.L.; Benjamin, R.C.; Moss, J.; Jacobson, M.K. Quantitative studies of inhibitors of ADP-ribosylation in vitro and in vivo. J. Biol. Chem. 1989, 264, 4312-4317.

68. Chen, G.; Zeller, W.J. Multiple effects of 3-aminobenzamide on DNA damage induced by cisplatin (DDP) in DDP-sensitive and -resistant rat ovarian tumor cell lines. Cancer Lett. 1992, 67, 27-33. [CrossRef]

69. Lu, Y.; Liu, Y.; Pang, Y.; Pacak, K.; Yang, C. Double-barreled gun: Combination of PARP inhibitor with conventional chemotherapy. Pharmacol. Ther. 2018, 188, 168-175. [CrossRef] 
70. Hengel, S.R.; Malacaria, E.; Constantino, L.F.d.; Bain, F.E.; Diaz, A.; Koch, B.G.; Yu, L.; Wu, M.; Pichierri, P.; Spies, M.A.; et al. Small-molecule inhibitors identify the RAD52-ssDNA interaction as critical for recovery from replication stress and for survival of BRCA2 deficient cells. Elife 2016, 5, e14740. [CrossRef]

71. Croteau, D.L.; Popuri, V.; Opresko, P.L.; Bohr, V.A. Human RecQ helicases in DNA repair, recombination, and replication. Annu. Rev. Biochem. 2014, 83, 519-552. [CrossRef]

72. Manthei, K.A.; Keck, J.L. The BLM dissolvasome in DNA replication and repair. Cell Mol. Life Sci. 2013, 70 , 4067-4084. [CrossRef] [PubMed]

73. Wu, L.; Hickson, I.D. The Bloom's syndrome helicase suppresses crossing over during homologous recombination. Nature 2003, 426, 870-874. [CrossRef] [PubMed]

74. Popuri, V.; Croteau, D.L.; Brosh, R.M., Jr.; Bohr, V.A. RECQ1 is required for cellular resistance to replication stress and catalyzes strand exchange on stalled replication fork structures. Cell Cycle 2012, 11, 4252-4265. [CrossRef]

75. Banerjee, T.; Brosh, R.M., Jr. RECQL: A new breast cancer susceptibility gene. Cell Cycle 2015, 14, 3540-3543. [CrossRef] [PubMed]

76. Parvathaneni, S.; Sharma, S. The DNA repair helicase RECQ1 has a checkpoint-dependent role in mediating DNA damage responses induced by gemcitabine. J. Biol. Chem. 2019, 294, 15330-15345. [CrossRef] [PubMed]

77. Schleicher, E.M.; Galvan, A.M.; Imamura-Kawasawa, Y.; Moldovan, G.L.; Nicolae, C.M. PARP10 promotes cellular proliferation and tumorigenesis by alleviating replication stress. Nucleic Acids Res. 2018, 46, 8908-8916. [CrossRef]

78. Budke, B.; Lv, W.; Kozikowski, A.P.; Connell, P.P. Recent Developments Using Small Molecules to Target RAD51: How to Best Modulate RAD51 for Anticancer Therapy? Chem. Med. Chem. 2016, 11, 2468-2473. [CrossRef]

79. Dungrawala, H.; Bhat, K.P.; le Meur, R.; Chazin, W.J.; Ding, X.; Sharan, S.K.; Wessel, S.R.; Sathe, A.A.; Zhao, R.; Cortez, D. RADX Promotes Genome Stability and Modulates Chemosensitivity by Regulating RAD51 at Replication Forks. Mol. Cell 2017, 67, 374-386.e5. [CrossRef]

80. Krajewska, M.; Fehrmann, R.S.; Schoonen, P.M.; Labib, S.; de Vries, E.G.; Franke, L.; van Vugt, M.A. ATR inhibition preferentially targets homologous recombination-deficient tumor cells. Oncogene 2015, 34, 3474-3481. [CrossRef]

81. Kim, D.; Liu, Y.; Oberly, S.; Freire, R.; Smolka, M.B. ATR-mediated proteome remodeling is a major determinant of homologous recombination capacity in cancer cells. Nucleic Acids Res. 2018, 46, 8311-8325. [CrossRef]

82. Lui, G.Y.L.; Grandori, C.; Kemp, C.J. CDK12: An emerging therapeutic target for cancer. J. Clin. Pathol. 2018, 71, 957-962. [CrossRef] [PubMed]

83. Krause, D.R.; Jonnalagadda, J.C.; Gatei, M.H.; Sillje, H.H.; Zhou, B.B.; Nigg, E.A.; Khanna, K. Suppression of Tousled-like kinase activity after DNA damage or replication block requires ATM, NBS1 and Chk1. Oncogene 2003, 22, 5927-5937. [CrossRef]

84. Lee, S.B.; Segura-Bayona, S.; Villamor-Paya, M.; Saredi, G.; Todd, M.A.M.; Attolini, C.S.; Chang, T.Y.; Stracker, T.H.; Groth, A. Tousled-like kinases stabilize replication forks and show synthetic lethality with checkpoint and PARP inhibitors. Sci. Adv. 2018, 4, eaat4985. [CrossRef] [PubMed]

85. Aarts, M.; Sharpe, R.; Garcia-Murillas, I.; Gevensleben, H.; Hurd, M.S.; Shumway, S.D.; Toniatti, C.; Ashworth, A.; Turner, N.C. Forced mitotic entry of S-phase cells as a therapeutic strategy induced by inhibition of WEE1. Cancer Discov. 2012, 2, 524-539. [CrossRef] [PubMed]

86. Pilie, P.G.; Tang, C.; Mills, G.B.; Yap, T.A. State-of-the-art strategies for targeting the DNA damage response in cancer. Nat. Rev. Clin. Oncol. 2018, 16, 81-104. [CrossRef] [PubMed]

87. Beke, L.; Kig, C.; Linders, J.T.; Boens, S.; Boeckx, A.; van Heerde, E.; Parade, M.; de Bondt, A.; van den Wyngaert, I.; Bashir, T.; et al. MELK-T1, a small-molecule inhibitor of protein kinase MELK, decreases DNA-damage tolerance in proliferating cancer cells. Biosci. Rep. 2015, 35. [CrossRef] [PubMed]

88. Bensimon, A.; Aebersold, R.; Shiloh, Y. Beyond ATM: The protein kinase landscape of the DNA damage response. FEBS Lett. 2011, 585, 1625-1639. [CrossRef] [PubMed]

89. Wang, Y.; Li, B.B.; Li, J.; Roberts, T.M.; Zhao, J.J. A Conditional Dependency on MELK for the Proliferation of Triple-Negative Breast Cancer Cells. iScience 2018, 9, 149-160. [CrossRef] 
90. Paiva, C.; Godbersen, J.C.; Berger, A.; Brown, J.R.; Danilov, A.V. Targeting neddylation induces DNA damage and checkpoint activation and sensitizes chronic lymphocytic leukemia B cells to alkylating agents. Cell Death Dis. 2015, 6, e1807. [CrossRef]

91. Soucy, T.A.; Dick, L.R.; Smith, P.G.; Milhollen, M.A.; Brownell, J.E. The NEDD8 Conjugation Pathway and Its Relevance in Cancer Biology and Therapy. Genes Cancer 2010, 1, 708-716. [CrossRef]

92. Milhollen, M.A.; Narayanan, U.; Soucy, T.A.; Veiby, P.O.; Smith, P.G.; Amidon, B. Inhibition of NEDD8-activating enzyme induces rereplication and apoptosis in human tumor cells consistent with deregulating CDT1 turnover. Cancer Res. 2011, 71, 3042-3051. [CrossRef] [PubMed]

93. Lin, J.J.; Milhollen, M.A.; Smith, P.G.; Narayanan, U.; Dutta, A. NEDD8-targeting drug MLN4924 elicits DNA rereplication by stabilizing $\mathrm{Cdt} 1$ in $\mathrm{S}$ phase, triggering checkpoint activation, apoptosis, and senescence in cancer cells. Cancer Res. 2010, 70, 10310-10320. [CrossRef]

94. Allen, C.; Ashley, A.K.; Hromas, R.; Nickoloff, J.A. More forks on the road to replication stress recovery. J. Mol. Cell Biol. 2011, 3, 4-12. [CrossRef] [PubMed]

95. Dupre, A.; Boyer-Chatenet, L.; Sattler, R.M.; Modi, A.P.; Lee, J.H.; Nicolette, M.L.; Kopelovich, L.; Jasin, M.; Baer, R.; Paull, T.T.; et al. A forward chemical genetic screen reveals an inhibitor of the Mre11-Rad50-Nbs1 complex. Nat. Chem. Biol. 2008, 4, 119-125. [CrossRef]

96. Sher, D.J. Neoadjuvant Chemoradiotherapy for Stage III Non-Small Cell Lung Cancer. Front Oncol. 2017, 7, 281. [CrossRef] [PubMed]

97. Stahl, M.; Budach, W. Definitive chemoradiotherapy. J. Thorac. Dis. 2017, 9, S792-S798. [CrossRef] [PubMed]

98. Schernberg, A.; del Campo, E.R.; Rousseau, B.; Matzinger, O.; Loi, M.; Maingon, P.; Huguet, F. Adjuvant chemoradiation for gastric carcinoma: State of the art and perspectives. Clin. Transl. Radiat. Oncol. 2018, 10, 13-22. [CrossRef]

99. Schmidt, E.V. Developing combination strategies using PD-1 checkpoint inhibitors to treat cancer. Semin. Immunopathol. 2018, 41, 21-30. [CrossRef]

100. Levy, B.; Saxena, A.; Schneider, B.J. Systemic therapy for small cell lung cancer. J. Natl. Compr. Canc. Netw. 2013, 11, 780-787. [CrossRef]

101. Mouw, K.W.; Goldberg, M.S.; Konstantinopoulos, P.A.; D’Andrea, A.D. DNA Damage and Repair Biomarkers of Immunotherapy Response. Cancer Discov. 2017, 7, 675-693. [CrossRef]

102. Carruthers, R.D.; Ahmed, S.U.; Ramachandran, S.; Strathdee, K.; Kurian, K.M.; Hedley, A.; Gomez-Roman, N.; Kalna, G.; Neilson, M.P.; Gilmour, L.; et al. Replication stress drives constitutive activation of the DNA damage response and radioresistance in glioblastoma stem-like cells. Cancer Res. 2018, 78, 5060-5071. [CrossRef] [PubMed]

103. Ruiz, S.; Mayor-Ruiz, C.; Lafarga, V.; Murga, M.; Vega-Sendino, M.; Ortega, S.; Fernandez-Capetillo, O. A Genome-wide CRISPR Screen Identifies CDC25A as a Determinant of Sensitivity to ATR Inhibitors. Mol. Cell 2016, 62, 307-313. [CrossRef] [PubMed]

104. O'Flanagan, C.H.; O'Shea, S.; Lyons, A.; Fogarty, F.M.; McCabe, N.; Kennedy, R.D.; O'Connor, R. IGF-1R inhibition sensitizes breast cancer cells to ATM-related kinase (ATR) inhibitor and cisplatin. Oncotarget 2016, 7, 56826-56841. [CrossRef] [PubMed]

105. Muralidharan, S.V.; Bhadury, J.; Nilsson, L.M.; Green, L.C.; McLure, K.G.; Nilsson, J.A. BET bromodomain inhibitors synergize with ATR inhibitors to induce DNA damage, apoptosis, senescence-associated secretory pathway and ER stress in Myc-induced lymphoma cells. Oncogene 2016, 35, 4689-4697. [CrossRef]

106. Muralidharan, S.V.; Einarsdottir, B.O.; Bhadury, J.; Lindberg, M.F.; Wu, J.; Campeau, E.; Bagge, R.O.; Stierner, U.; Ny, L.; Nilsson, L.M.; et al. BET bromodomain inhibitors synergize with ATR inhibitors in melanoma in melanoma. Cell Death Dis. 2017, 8, e2982. [CrossRef]

107. Carrassa, L.; Chila, R.; Lupi, M.; Ricci, F.; Celenza, C.; Mazzoletti, M.; Broggini, M.; Damia, G. Combined inhibition of Chk1 and Wee1: In vitro synergistic effect translates to tumor growth inhibition in vivo. Cell Cycle 2012, 11, 2507-2517. [CrossRef]

108. Pfister, S.X.; Markkanen, E.; Jiang, Y.; Sarkar, S.; Woodcock, M.; Orlando, G.; Mavrommati, I.; Pai, C.C.; Zalmas, L.P.; Drobnitzky, N.; et al. Inhibiting WEE1 Selectively Kills Histone H3K36me3-Deficient Cancers by dNTP Starvation. Cancer Cell 2015, 28, 557-568. [CrossRef]

109. Aarts, M.; Bajrami, I.; Herrera-Abreu, M.T.; Elliott, R.; Brough, R.; Ashworth, A.; Lord, C.J.; Turner, N.C. Functional Genetic Screen Identifies Increased Sensitivity to WEE1 Inhibition in Cells with Defects in Fanconi Anemia and HR Pathways. Mol. Cancer Ther. 2015, 14, 865-876. [CrossRef] 
110. Lallo, A.; Frese, K.K.; Morrow, C.J.; Sloane, R.; Gulati, S.; Schenk, M.W.; Trapani, F.; Simms, N.; Galvin, M.; Brown, S.; et al. The Combination of the PARP Inhibitor Olaparib and the WEE1 Inhibitor AZD1775 as a New Therapeutic Option for Small Cell Lung Cancer. Clin. Cancer Res. 2018, 24, 5153-5164. [CrossRef]

111. Perez, R.P.; Lewis, L.D.; Beelen, A.P.; Olszanski, A.J.; Johnston, N.; Rhodes, C.H.; Beaulieu, B.; Ernstoff, M.S.; Eastman, A. Modulation of cell cycle progression in human tumors: A pharmacokinetic and tumor molecular pharmacodynamic study of cisplatin plus the Chk1 inhibitor UCN-01 (NSC 638850). Clin. Cancer Res. 2006, 12, 7079-7085. [CrossRef]

112. Wallez, Y.; Dunlop, C.R.; Johnson, T.I.; Koh, S.B.; Fornari, C.; Yates, J.W.; de Fernandez, S.B.; Lau, A.; Richards, F.M.; Jodrell, D.I. The ATR inhibitor AZD6738 synergizes with gemcitabine in vitro and in vivo to induce pancreatic ductal adenocarcinoma regression. Mol. Cancer Ther. 2018, 17, 1670-1682. [CrossRef]

113. Koh, S.B.; Courtin, A.; Boyce, R.J.; Boyle, R.G.; Richards, F.M.; Jodrell, D.I. CHK1 Inhibition Synergizes with Gemcitabine Initially by Destabilizing the DNA Replication Apparatus. Cancer Res. 2015, 75, 3583-3595. [CrossRef]

114. Rajeshkumar, N.V.; de Oliveira, E.; Ottenhof, N.; Watters, J.; Brooks, D.; Demuth, T.; Shumway, S.D.; Mizuarai, S.; Hirai, H.; Maitra, A.; et al. MK-1775, a potent Wee1 inhibitor, synergizes with gemcitabine to achieve tumor regressions, selectively in p53-deficient pancreatic cancer xenografts. Clin. Cancer Res. 2011, 17, 2799-2806. [CrossRef]

115. Garcia, K.; Blank, J.L.; Bouck, D.C.; Liu, X.J.; Sappal, D.S.; Hather, G.; Cosmopoulos, K.; Thomas, M.P.; Kuranda, M.; Pickard, M.D.; et al. Nedd8-activating enzyme inhibitor MLN4924 provides synergy with mitomycin C through interactions with ATR, BRCA1/BRCA2, and chromatin dynamics pathways. Mol. Cancer Ther. 2014, 13, 1625-1635. [CrossRef]

116. Seto, T.; Esaki, T.; Hirai, F.; Arita, S.; Nosaki, K.; Makiyama, A.; Kometani, T.; Fujimoto, C.; Hamatake, M.; Takeoka, H.; et al. Phase I, dose-escalation study of AZD7762 alone and in combination with gemcitabine in Japanese patients with advanced solid tumours. Cancer Chemother. Pharmacol. 2013, 72, 619-627. [CrossRef]

117. Sausville, E.; Lorusso, P.; Carducci, M.; Carter, J.; Quinn, M.F.; Malburg, L.; Azad, N.; Cosgrove, D.; Knight, R.; Barker, P.; et al. Phase I dose-escalation study of AZD7762, a checkpoint kinase inhibitor, in combination with gemcitabine in US patients with advanced solid tumors. Cancer Chemother. Pharmacol. 2014, 73, 539-549. [CrossRef]

118. Sato, H.; Niimi, A.; Yasuhara, T.; Permata, T.B.M.; Hagiwara, Y.; Isono, M.; Nuryadi, E.; Sekine, R.; Oike, T.; Kakoti, S.; et al. DNA double-strand break repair pathway regulates PD-L1 expression in cancer cells. Nat. Commun. 2017, 8, 1751. [CrossRef]

119. Keytruda (Pembrolizumab) [Package Insert]. Merck Sharp \& Dohme Corp., Whitehouse Station, NJ 08889, USA. Available online: https://www.merck.com/product/usa/pi_circulars/k/keytruda/keytruda_pi.pdf (accessed on 29 July 2018).

120. Chatzinikolaou, G.; Karakasilioti, I.; Garinis, G.A. DNA damage and innate immunity: Links and trade-offs. Trends Immunol. 2014, 35, 429-435. [CrossRef]

121. Brown, J.S.; Sundar, R.; Lopez, J. Combining DNA damaging therapeutics with immunotherapy: More haste, less speed. Br. J. Cancer 2018, 118, 312-324. [CrossRef]

122. Nogueira, V.; Hay, N. Molecular pathways: Reactive oxygen species homeostasis in cancer cells and implications for cancer therapy. Clin. Cancer Res. 2013, 19, 4309-4314. [CrossRef]

123. Burhans, W.C.; Weinberger, M. DNA replication stress, genome instability and aging. Nucleic Acids Res. 2007, 35, 7545-7556. [CrossRef]

124. Diehn, M.; Cho, R.W.; Lobo, N.A.; Kalisky, T.; Dorie, M.J.; Kulp, A.N.; Qian, D.; Lam, J.S.; Ailles, L.E.; Wong, M.; et al. Association of reactive oxygen species levels and radioresistance in cancer stem cells. Nature 2009, 458, 780-783. [CrossRef]

125. Wells, C.E.; Bhaskara, S.; Stengel, K.R.; Zhao, Y.; Sirbu, B.; Chagot, B.; Cortez, D.; Khabele, D.; Chazin, W.J.; Cooper, A.; et al. Inhibition of histone deacetylase 3 causes replication stress in cutaneous $\mathrm{T}$ cell lymphoma. PLoS ONE 2013, 8, e68915. [CrossRef]

126. Namdar, M.; Perez, G.; Ngo, L.; Marks, P.A. Selective inhibition of histone deacetylase 6 (HDAC6) induces DNA damage and sensitizes transformed cells to anticancer agents. Proc. Natl. Acad. Sci. USA 2010, 107, 20003-20008. [CrossRef] 
127. Conti, C.; Leo, E.; Eichler, G.S.; Sordet, O.; Martin, M.M.; Fan, A.; Aladjem, M.I.; Pommier, Y. Inhibition of histone deacetylase in cancer cells slows down replication forks, activates dormant origins, and induces DNA damage. Cancer Res. 2010, 70, 4470-4480. [CrossRef]

128. Tanaka, N.; Patel, A.A.; Tang, L.; Silver, N.L.; Lindemann, A.; Takahashi, H.; Jaksik, R.; Rao, X.; Kalu, N.N.; Chen, T.C.; et al. Replication Stress Leading to Apoptosis within the S-phase Contributes to Synergism between Vorinostat and AZD1775 in HNSCC Harboring High-Risk TP53 Mutation. Clin. Cancer Res. 2017, 23, 6541-6554. [CrossRef]

129. Conforti, F.; Sayan, A.E.; Sreekumar, R.; Sayan, B.S. Regulation of p73 activity by post-translational modifications. Cell Death Dis. 2012, 3, e285. [CrossRef]

130. Dotiwala, F.; Eapen, V.V.; Harrison, J.C.; Arbel-Eden, A.; Ranade, V.; Yoshida, S.; Haber, J.E. DNA damage checkpoint triggers autophagy to regulate the initiation of anaphase. Proc. Natl. Acad. Sci. USA 2013, 110, E41-E49. [CrossRef]

131. Gilmartin, A.G.; Faitg, T.H.; Richter, M.; Groy, A.; Seefeld, M.A.; Darcy, M.G.; Peng, X.; Federowicz, K.; Yang, J.; Zhang, S.Y.; et al. Allosteric Wip1 phosphatase inhibition through flap-subdomain interaction. Nat. Chem. Biol. 2014, 10, 181-187. [CrossRef]

132. Gudkov, A.V.; Komarova, E.A. Prospective therapeutic applications of p53 inhibitors. Biochem. Biophys. Res. Commun. 2005, 331, 726-736. [CrossRef]

133. Gad, H.; Koolmeister, T.; Jemth, A.S.; Eshtad, S.; Jacques, S.A.; Strom, C.E.; Svensson, L.M.; Schultz, N.; Lundback, T.; Einarsdottir, B.O.; et al. MTH1 inhibition eradicates cancer by preventing sanitation of the dNTP pool. Nature 2014, 508, 215-221. [CrossRef]

134. Huber, K.V.; Salah, E.; Radic, B.; Gridling, M.; Elkins, J.M.; Stukalov, A.; Jemth, A.S.; Gokturk, C.; Sanjiv, K.; Stromberg, K.; et al. Stereospecific targeting of MTH1 by (S)-crizotinib as an anticancer strategy. Nature 2014, 508, 222-227. [CrossRef]

135. Zimmerman, K.M.; Jones, R.M.; Petermann, E.; Jeggo, P.A. Diminished origin-licensing capacity specifically sensitizes tumor cells to replication stress. Mol. Cancer Res. 2013, 11, 370-380. [CrossRef]

136. Steckel, M.; Molina-Arcas, M.; Weigelt, B.; Marani, M.; Warne, P.H.; Kuznetsov, H.; Kelly, G.; Saunders, B.; Howell, M.; Downward, J.; et al. Determination of synthetic lethal interactions in KRAS oncogene-dependent cancer cells reveals novel therapeutic targeting strategies. Cell Res. 2012, 22, 1227-1245. [CrossRef]

137. Ren, L.; Chen, L.; Wu, W.; Garribba, L.; Tian, H.; Liu, Z.; Vogel, I.; Li, C.; Hickson, I.D.; Liu, Y. Potential biomarkers of DNA replication stress in cancer. Oncotarget 2017, 8, 36996-37008. [CrossRef]

138. Gadaleta, M.C.; Iwasaki, O.; Noguchi, C.; Noma, K.; Noguchi, E. Chromatin immunoprecipitation to detect DNA replication and repair factors. Methods Mol. Biol. 2015, 1300, 169-186.

139. Syljuasen, R.G.; Sorensen, C.S.; Hansen, L.T.; Fugger, K.; Lundin, C.; Johansson, F.; Helleday, T.; Sehested, M.; Lukas, J.; Bartek, J. Inhibition of human Chk1 causes increased initiation of DNA replication, phosphorylation of ATR targets, and DNA breakage. Mol. Cell Biol. 2005, 25, 3553-3562. [CrossRef]

140. Edwards, S.L.; Brough, R.; Lord, C.J.; Natrajan, R.; Vatcheva, R.; Levine, D.A.; Boyd, J.; Reis-Filho, J.S.; Ashworth, A. Resistance to therapy caused by intragenic deletion in BRCA2. Nature 2008, 451, 1111-1115. [CrossRef]

141. Jaspers, J.E.; Kersbergen, A.; Boon, U.; Sol, W.; van Deemter, L.; Zander, S.A.; Drost, R.; Wientjens, E.; Ji, J.; Aly, A.; et al. Loss of 53BP1 causes PARP inhibitor resistance in Brca1-mutated mouse mammary tumors. Cancer Discov. 2013, 3, 68-81. [CrossRef] [PubMed]

142. Kondrashova, O.; Nguyen, M.; Shield-Artin, K.; Tinker, A.V.; Teng, N.N.H.; Harrell, M.I.; Kuiper, M.J.; Ho, G.Y.; Barker, H.; Jasin, M.; et al. Secondary Somatic Mutations Restoring RAD51C and RAD51D Associated with Acquired Resistance to the PARP Inhibitor Rucaparib in High-Grade Ovarian Carcinoma. Cancer Discov. 2017, 7, 984-998. [CrossRef]

143. Haynes, B.; Murai, J.; Lee, J.M. Restored replication fork stabilization, a mechanism of PARP inhibitor resistance, can be overcome by cell cycle checkpoint inhibition. Cancer Treat. Rev. 2018, 71, 1-7. [CrossRef] [PubMed]

144. Rottenberg, S.; Jaspers, J.E.; Kersbergen, A.; van der Burg, E.; Nygren, A.O.; Zander, S.A.; Derksen, P.W.; de Bruin, M.; Zevenhoven, J.; Lau, A.; et al. High sensitivity of BRCA1-deficient mammary tumors to the PARP inhibitor AZD2281 alone and in combination with platinum drugs. Proc. Natl. Acad. Sci. USA 2008, 105, 17079-17084. [CrossRef] 
145. Oplustil O'Connor, L.; Rulten, S.L.; Cranston, A.N.; Odedra, R.; Brown, H.; Jaspers, J.E.; Jones, L.; Knights, C.; Evers, B.; Ting, A.; et al. The PARP Inhibitor AZD2461 Provides Insights into the Role of PARP3 Inhibition for Both Synthetic Lethality and Tolerability with Chemotherapy in Preclinical Models. Cancer Res. 2016, 76, 6084-6094. [CrossRef] [PubMed]

146. Oplustilova, L.; Wolanin, K.; Mistrik, M.; Korinkova, G.; Simkova, D.; Bouchal, J.; Lenobel, R.; Bartkova, J.; Lau, A.; O'Connor, M.J.; et al. Evaluation of candidate biomarkers to predict cancer cell sensitivity or resistance to PARP-1 inhibitor treatment. Cell Cycle 2012, 11, 3837-3850. [CrossRef] [PubMed]

147. Restelli, V.; Chila, R.; Lupi, M.; Rinaldi, A.; Kwee, I.; Bertoni, F.; Damia, G.; Carrassa, L. Characterization of a mantle cell lymphoma cell line resistant to the Chk1 inhibitor PF-00477736. Oncotarget 2015, 6, 37229-37240. [CrossRef] [PubMed]

(C) 2020 by the authors. Licensee MDPI, Basel, Switzerland. This article is an open access article distributed under the terms and conditions of the Creative Commons Attribution (CC BY) license (http://creativecommons.org/licenses/by/4.0/). 